\title{
INVENTARISASI PENYAKIT PADA DUA VARIETAS LOKAL BAWANG MERAH (Allium ascalonicum L.) BIMA BREBES DAN TRISULA
}

\author{
Oleh \\ Widya Sari*) \\ Siti Aulia Inayah**) \\ Email : widya.sari@unsur.ac.id
}

\begin{abstract}
Abstrak
Serangan patogen tumbuhan merupakan salah satu kendala yang di hadapi dalam budidaya bawang merah, beberapa diantaranya yaitu cendawan, bakteri, dan virus yang mampu menurunkan hasil produksi bawang merah. Varietas bawang Bima Brebes merupakan varietas yang paling disukai oleh petani dan adaptif pada dataran rendah sedangkan Varietas Trisula merupakan varietas yang bisa ditanam di luar musim ( off season), sehingga bisa ditanam pada musim penghujan dan adaptif pada dataran rendah. Tujuan dari penelititan ini adalah untuk mengetahui jenis dan gejala penyakit pada tanaman bawang merah varietas Bima Brebes dan varietas Trisula yang ditanam di dataran tinggi. Penelitian ini dilakukan di Balai Penelitian Tanaman Hias (BALITHI) Kabupaten cianjur, Provinsi Jawa Barat pada bulan Agustus-September 2019. Metode yang digunakan dalam penelitian ini adalah metode observasi yang dilakukan terhadap tanaman bawang merah varietas Bima Brebes dan Trisula. Inventarisasi penyakit dilakukan dengan pengamatan gejala serangan patogen pada daun, umbi maupun akar tanaman bawang merah. Hasil penelitian menunjukkan penyakit yang menginfeksi pada varietas Bima Brebes yaitu penyakit Bercak Ungu pada daun yang di sebabkan oleh cendawan (Alltenaria porri), dan penyakit mosaik kuning yang di sebabkan oleh virus (OnionYellow Dwarf Virus) pada bagian daun tua.Sedangkan penyakit yang menginfeksi pada varietas Trisula yaitu penyakit Moler yang disebabkan oleh cendawan Fusarium oxysporum f.sp.cepae, penyakit Bercak Ungu yang disebabkan oleh cendawan (Alltenaria porri), dan penyakit Mosaik Kuning yang di sebabkan oleh (Onion Yellow Dwarf Virus). Varietas Bima Brebes lebih tahan terhadap infeksi cendawan Fusarium oxysporum f.sp.cepae dibanding varietas Trisula.
\end{abstract}

Kata Kunci : Bercak Ungu, Bima Brebes, Moler, Mosaik Kuning, Trisula.

\begin{abstract}
The attack of plant pathogens is one of the obstacles faced in the cultivation of shallots, some of which are fungi, bacteria, and viruses which can reduce the yield of shallots. The Bima Brebes onion variety is the variety most favored by farmers and adaptive in the lowlands while the Trisula variety can be planted off season, so that it can be planted in the rainy season and adaptive in the lowlands. The purpose of this research was to determine the differences in diseases of the Bima Brebes and Trisula varieties grown in the highlands. This research was conducted at the Ornamental Plants Research Center (BALITHI), Cianjur Regency, West Java Province in Angust-September 2019. The method used in this study was a observation method which was carried out on shallot plants of Bima Brebes and Trisula varieties. Disease inventory was carried out by observing the symptoms of pathogen attack on the leaves, tubers and roots of shallot plants. The results showed that the diseases that infect the Bima Brebes variety were purple spot disease on leaves caused by a fungus (Alltenaria porri), and yellow mosaic disease caused by a virus (Onion Yellow Dwarf Virus) on old leaves. While the diseases that infect the Trisula variety were Moler disease caused by the fungus Fusarium
\end{abstract}


oxysporum f.sp.cepae, purple spot disease caused by fungi (Alltenaria porri), and yellow mosaic disease caused by Onion Yellow Dwarf Virus. Bima Brebes variety was more resistant to Fusarium oxysporum f.sp.cepae fungi infection than Trisula variety.

Keywords : Bima Brebes, Moler, Purple Spot, Trisula, Yellow Mosaic.

*) Dosen Fakultas Sains Terapan UNSUR.

**) Alumni Fakultas Sains Terapan UNSUR. 


\section{PENDAHULUAN}

Bawang merah adalah salah satu komoditi unggulan di beberapa daerah diIndonesia, yang digunakan sebagai bumbu masakan dan memiliki kandungan beberapazat yang bermanfaat bagi kesehatan,seperti zat anti kanker dan pengganti antibiotik, menurunkan tekanan darah, kolestrol serta penurunan kadar guladarah (Irawan, 2010).

Sejak tahun 1984-2012 Balai Penelitian Tanaman Sayuran (Balitsa) telah melepas atau mendaftarkan 11 varietas bawang merah yang cocok ditanam di dataran rendah sampai tinggi. Akan tetapi, ada beberapa varietas bawang merah dataran rendah yang juga cocok ditanam di dataran tinggi yaitu varietas Sembrani, Pikatan, Trisula, Pancasona dan Mentes. Selain itu ada pula varietas yaitu varietas Trisula dan Sembrani yang cocok ditanam di luar musim atau pada musim hujan (off-season) (Waluyo dan Sinaga, 2015).

Serangan patogen tumbuhan merupakan salah satu kendala yang dihadapi dalam budidaya bawang merah seperti infeksi penyakit yang di sebabkan oleh cendawan, bakteri, dan virus yang mampu menurunkan hasil produksi bawang merah. Beberapa penyakit yang umum menginfeksi bawang merah antara lain : a. Bercak Ungu, penyakit ini di sebabkan oleh cendawan Altenaria porri, b. Moler, penyakit ini di sebabkan oleh cendawan Fusarium oxysporum, c. Busuk Daun (Antraknosa), penyakit ini di sebabkan oleh cendawan Collectricum gloeosporiodes, d. Virus Mosaik Bawang (Onion Yellow Dwarf Virus), penyakit mosaik bawang ini di sebabkan oleh onion yellow dwarf virus. e. Mati Pucuk, penyakit ini disebabkan oleh cendawan Phytophthora porrif. Embun Bulu, penyakit ini disebabkan oleh cendawan Peronaspora destructor BPTPH, 2018.

Bawang merah varietas bima adalah salah satu varietas yang sebagian besar yang sering di budidayan oleh petani yang berada di brebes, bantul, nganjuk. Permintaan baik dari pasar atau konsumen yang sering tersedia adalah varietas bima, bawang merah varietas bima biasanya digunakan untuk bumbu masak, ciri morfologi pada bawang merah varietas bima ini ukuran daun lebih kecil dan warna daun lebih agak hijau pucat dari varietas trisula, ukran dan bobot umbi lebih kecil dan memiliki warna agak kemerahan (Sakti et al., 2017)

Selanjutnya Sakti et al.,(2017) menyatakan bahwa bawang merah varietas Trisula mempunyai ciri warna umbi yang lebih keunguan, pada saat masa vegetatif menuju ke generatif umbi bawang muncul pada permukaan tanah, ukuran daun yang lebih besar dan warna daun lebih hijau tua, ukuran dan bobot umbi lebih besar. Pada saat ini varietas trisula masih dalam tahap pengembangan ke penangkar bawang merah.

Balitsa melakukan pengujian penanaman dua varietas tanaman Bawang Merah di kebun percobaan Balithi yaitu Varietas Bima Brebes dan Varietas Trisula. Viretas Bima Brebes dan varietas Trisula adalah varietas lokal yang cocok ditanami di dataran rendah. Inventarisasi penyakit pada kedua varietas tersebut belum pernah dilakukan. Oleh karena itu penulis melakukan penelitian ini untuk mengetahui penyakit-penyakit yang menyerang kedua varietas tersebut.

Tujuan dari penelititan ini adalah untuk : 1. Mengetahui gejala dan tanda penyakit yang menyerang pada tanaman bawang merah, 2. Mengetahui jenis patogen penyebab penyakit pada tanaman bawang merah varietas Bima Brebes dengan varietas Trisula.

\section{METODE PENELITIAN}

\section{Waktu dan Tempat}

Penelitian ini dilakukan di dilakukan di Balai Penellitian Tanaman Hias (BALITHI), Kampung Landbouw, Kecamatan Cipanas, Kabupaten cianjur, Provinsi Jawa Barat pada bulan AgustusSeptember 2019.

\section{Metode Penelitian}

Penelitian ini bersifat kualitatif yang dilaksanakan melalui obsevasi yakni mengambarkan keadaan yang sebenarnya 
dari hasil pengamatan terhadap objek penelitian sehingga data yang diperoleh sesuai dengan sampel yang diamati. Jumlah total kebun bawang merah terdapat 7 blok. 6 blok di tanami bawang merah dengan varietas bima brebes dengan sumber benih daru umbi ke biji, sedangkan 1 blok lagi di tanami bawang merah varietas trisula sumber benih dari biji ke biji (TSS).

Metode observasi dilakukan terhadap tanaman bawang merah varietas Bima Brebes dan Trisula yang ditanam di dataran tinggi. Inventarisasi penyakit dilakukan dengan pengamatan gejala serangan patogen pada daun, umbi maupun akar tanaman bawang merah. Gejala-gejala yang diamati dibandingkan dengan buku panduan teknis Pengenalan Hama dan Penyakit pada Tanaman Bawang Merah (Udiarto et al., 2005).

\section{Pelaksanaan Penelitian}

a. Pengamatan gejala dan tanda penyakit pada tanaman bawang merah varietas Bima Brebes dan Trisula

Pengamatan gejala dilakukan utuk melihat kelainan atau penyimpangan darikeadaan normal yang ditunjukkan oleh tumbuhan atautanaman. Gejala yang muncul kemudian dikelompokkan menjadi : Hiperplasia (Keriting, Kudis, Tumor dan Proliferasi), Hipoplasia (kerdil), Perubahan warna (Menguning atau Bercak), Layu, Kematian jaringan (nekrosis).

Pengamatan tanda dilakukan dengan mata biasa tanpa alat pembesaran (makroskopis)dan alat pembesar (lup/mikroskop).Tanda yaitu kenampakan makroskopis patogen atau bagiannya memegang peranan penting, bahkan lebih penting dari gejala. Tanda penyakit merupakan tubuh atau bagiantubuh patogen yang sebagai besar dibentuk di dalam seldan atau disekitar jaringan tanaman sebagai bentukkegiatan perbanyakan dan akan digunakan oleh patogenuntuk melakukan untuk penyebaran. b. Penentuan jenis patogen penyebab penyakit pada tanaman bawang merah varietas Bima Brebes dan Trisula

Patogen yang menginfeksi tanaman dapat diketahui dari gejala dan tanda yang muncul pada tanaman, kemudian dirujuk kepada buku panduan teknis hama dan penyakit tanaman bawang merah, sehingga bisa disimpulkan patogen penyebab penyakit tersebut.

\section{Teknik Pengumpulan Data}

Teknik pengumpulan data dalam penelitian ini melalui studi pustaka dan studi lapangan:

1. Studi pustaka

Studi pustaka dilakukan dengan cara mengumpulkan literatur yang berkaitan dengan topik penelitian ini. Literatur yang digunakan berasal dari buku-buku, teks, jurnal ilmiah, situs-situs di internet serta bacaan-bacaan lain yang kemudian dipelajari dan ditelaah.

2. Studi lapangan:

Studi ini dilakukan dengan cara mengunjungi tempat yangakan diteliti dan pengumpulan data dilakukan secara langsung. Hal ini meliputi :

a. Wawancara yaitu teknik pengumpulan data dengan cara mengadakan tanya jawab secara langsung dengan narasumber yang terkait.

b. Observasi yaitu teknik pengumpulan data dengan cara melakukan pengamatan secara langsung kepada objek yang di teliti.

\section{Teknik Analisis Data}

Teknik analisis data kualitatif dilakukan secara analisis deskriptif, yaitu menggambarkan keadaan yang ada berdasarkan fakta-fakta yang tampak atau apa adanya kemudian dibandingkan dengan literatur terkait. 


\section{HASIL DAN PEMBAHASAN}

\section{Gejala dan Tanda Penyakit}

\section{a. Bercak Ungu}

Gejala bercak ungu terlihat pada tanaman bawang yang telah memasuki fase generatif dengan tinggi tanaman sekitar $40 \mathrm{~cm}$. Gejala khas yang tampak adalah nekrosis atau matinya bagian tanaman dari sekumpulan sel yang terbatas dalam jaringan tertentu dan pada bagian salah satu tanaman terlihat adanya bercak hitam. Gejala selanjutnya yaitu gejala klorisis / nekrosis rusaknya kloroplas menyebabkan menguningnya bagian-bagian yang lazimnya berwarna hijau (Gambar 1a).

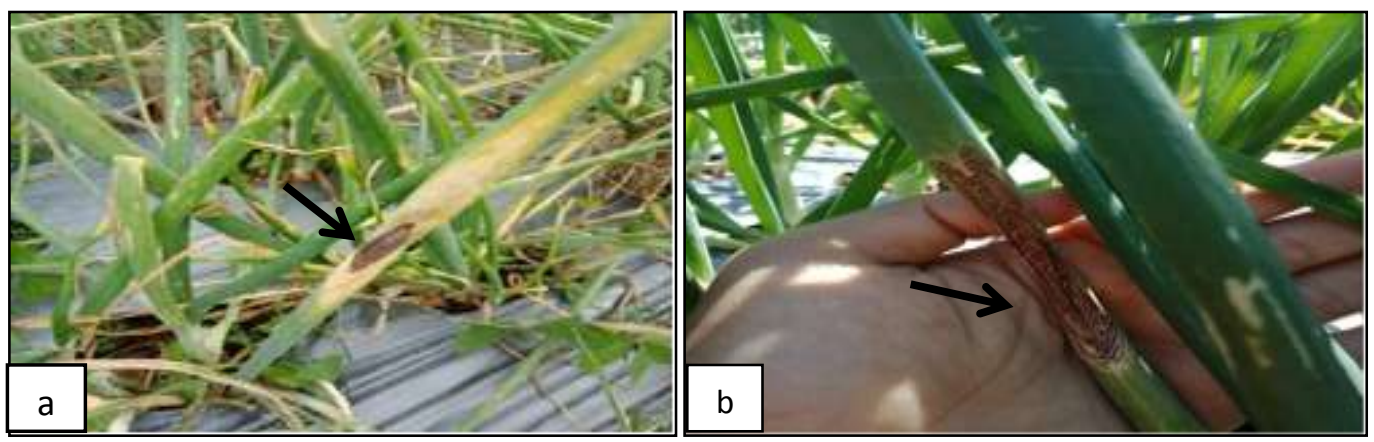

Gambar 1. Gejala Bercak Ungu pada varietas Bima Brebes (a) dan varietas Trisula (b)

Gejala nekrosis ditandai dengan matinya bagian tanaman dari sekumpulan sel dalam jaringan tertentu dan kemudian terlihat bercak-bercak kehitaman. Gejala serangan penyakit bercak ungu : bercak berukuran kecil, melengkung dengan warna putih hingga kelabu. Apabila ukuran bercak membesar, warna berubah keunguan dan tampak bercincin. Pinggiran bercak berwarna merah keunguan yang dikelilingi oleh zona berwarna kuning. Apabila cuaca lembab, warna permukaan bercak berubah menjadi coklat kehitaman, dengan ujung daun yang mengering. Jumlah bercak pada dau tua lebih banyak dari pada pada daun muda. (Gambar 1b.).

Tanda bercak pada daun yang terinfeksi cukup terlihat sangat jelas, memiliki miselium cendawan dengan struktur yang mengering, dan menyerang pada bagian tangkai bunga pada saat masa generatif. Tandabercak ungu yang dapat dilihat secara visual, mayoritas menyerang pada bagian daun tua, bercak hitam tedapat tanda berupa misellium jamur berwarna ungu kehitaman yang cukup jelas dengan tepi berwarna kuning. Biasanya daun tersebut menjadi layu dan menguning dari ujung daun dan menjalar menuju pangkal daun. Gejala dan tanda ini terdapat pada kedua varietas bawang merah Bima Brebes dan Trisula.

\section{b. Mosaik Kuning}

Gejala serangan penyakit secara visual pada tanaman bawang merah mulai terlihat pada umur 40 HST. Berupa mosaik kuning disertai dengan garis-garis vertikal berwarna kuning yang tersambung dan terputus-putus, klorisis, daun bergaris hijau, dan menjadi kecil (Gambar 2a dan $2 b)$. 

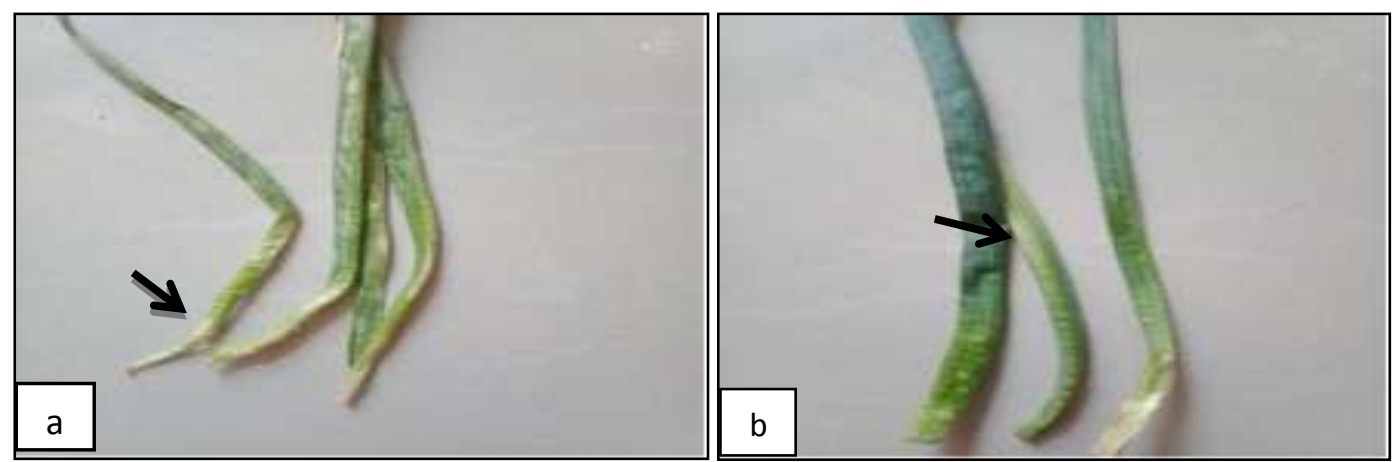

Gambar 2. Gejala mosaik kuning: a. Varietas Bima Brebes, b. Varietas Trisula.

Gejala terdapat bagian daun, dan pada bagian bawah daun terdapat kutu daun yang merupakan vektor dari patogen. Bagian daun mengalami nekrosis dan terdapat bercak garis bergelombang yang berwarna kuning garis strip tersebut berbentuk horizontal. Daun yang lazimnya berwarna hijau menjadi warna hijau pucat (mengalami klorisis). Gejala dan tanda ini terdapat pada ke dua varietas bawang merah Bima Brebes dan Trisula.

\section{c. Melengkung Terpelintir (Moler)}

Gejala Moler meperlihatkan ciri yang khas yaitu warna daun menjadi kuning dan bentuknya melengkung terpelintir. Hal ini menyebabkan tanaman menjadi cepat layu, kurus kekuningan dan terkulai seperti akan roboh. Pada bagian dasar umbi lapis terlihat koloni cendawan berwarna putih dan apabila dipotong membujur maka terlihat adanya pembusukan yang berawal dari dasar umbi meluas ke atas maupun ke samping (Gambar 3). Gejala dan tanda ini hanya terdapat pada varietas bawang merah Trisula.

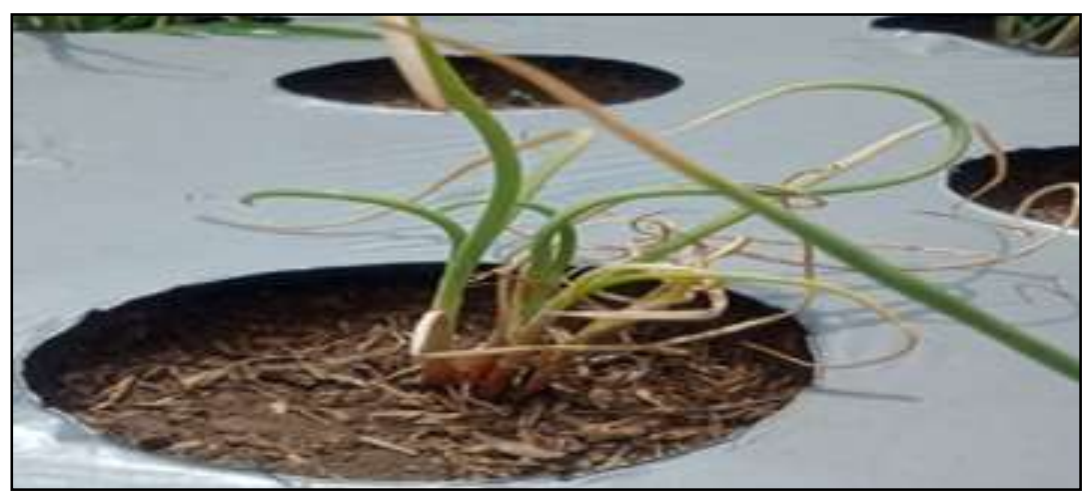

Gambar 3. Gejala Moler pada Varietas Trisula.

\section{Jenis patogen penyebab penyakit pada tanaman bawang merah}

Berdasarkan hasil pengamatan

Gejala dan Tanda yang didapatkan pada kedua varietas bawang merah Bima Brebes dan Trisula, dilakukan diagnosa dengan merujuk kepada buku Panduan Teknis Hama dan Penyakit pada tanaman Bawang Merah. Penyebab munculnya penyakit tanaman secara garis besar dibagi menjadi 3 golongan patogen utama, yaitu jamur (cendawan), bakteri, dan virus.

\section{a. Penyakit Bercak ungu (Altenaria porri)}

Gejala penyakit ini disebabkan oleh cendawan Altenaria porri. Penyebaran terjadi oleh media angin, penularan di sebabkan oleh tular angin atau udara. Pada hamparan kebun bawang merah berdasarkan hasil pengamatan lapangan di temukan 1 penyakit bercak ungu pada tanaman bawang merah di salah satu rumpun. Pada varietas bima brebes dari beberapa bedengan per satu blok hasil 
dari pengamatan langsung di lapangan mayoritas penyakit yang menginfeksi lebih banyak penyakit bercak ungu (Altenaria porri) dengan bentuk bercak dan warna berbeda dengan penyakit bercak ungu yang menyerang pada varietas trisula. Infeksi dari penyakit ini ditemukan pada saat masa vegetatif dan generatif, bahkan di tangkai bunga banyak di temukan infeksi dari penyakit bercak ungu.

Nasiroh et al. (2015), menyatakan apabila cendawan patogen ini menginfeksi pada saat tanaman bawang merah membentuk umbi, dapat menyebabkan kerugian mencapai $30-40 \%$, karena patogen ini menyerang semua bagian tanaman yaitu, daun, batang serta umbi. Akan tetapi tanaman yang masih muda juga dapat terinfeksi berat pada saat musim penghujan, karena kondisi lingkungan yang mendukung perkembangan penyakit.

\section{b. Virus Mosaik Kuning}

Penyakit mosaik kuning pada bawang merah di sebabkan oleh Onion Yellow Dwarf Virus (OYDV). Penyakit ini di tularkan melalui umbi yang di sebabkan oleh virus, penyakit virus sifatnya sistemik apabila sudah di dalam umbi sulit untuk di kendalikan, serta dapat membawa masalah baru pada pertanaman lainnya. Menurut Walkey (1990), serangan OYDV dapat menyebabkan kehilangan hasil masingmasing sebesar 54\%. Penularan penyakit virus pada bawang merah di lapangan dilakukan oleh serangga vektor kutu daun Myzus persicae, (Walkey 1990). Kutu daun selalu menjadi masalah di daerah tropis, karena kutu daun bisa selalu aktif dan berkembang biak sepanjang waktu karena inangnya tidak mengalami masa istirahat (Duriat 1985).

Shahraeen et al. (2008) menyatakan bahwa pada umumnya bawang merah diperbanyak secara vegetatif menggunakan umbi., hal ini menyebabkan virus ini cepat berkembang dan terakumulasi pada pertanaman bawang merah karena dapat menular melalui umbi (tular umbi).

\section{c. Penyakit Moler}

Pada Varietas Trisula mayoritas penyakit yang menginfeksi yaitu Moler yang disebabkan cendawan Fusarium oxysporum f.sp. cepae yang mengakibatkan gejala kerusakan nekrosis dan klorosis hampir semua bagian tanaman terinfeksi oleh cendawan F. oxysporum f.sp. cepae, tetapi pada varietas Bima Brebes tidak ditemukan gejala dan tanda dari infeksi $F$. oxysporum f.sp.cepae.

Penyakit ini merupakan salah satu penyakit penting pada tanaman bawang merah dan telah menimbulkan banyak kerugian di beberapa sentra produksi hingga 50\% (Wiyatiningsih et al., 2009)

\section{KESIMPULAN}

1. Terdapat beberapa gejala dan tanda penyakit pada tanaman bawang merah varietas Bima Brebes dan Trisula yaitu : bercak ungu dengan miselium kering terutama pada daun tua, mosaik kuning dengan gejala daun mengalami nekrosis dan terdapat bercak garis bergelombang yang berwarna kuning dan terdapat kutu daun di bagian bawah daun, moler dengan gejala daun menguning dan terpelintir (moler). Tanaman menjadi cepat layu, tanaman terkulai seperti akan roboh, dan di dasar umbi lapis terlihat koloni jamur berwarna putih.

2. Beberapa penyakit yang menginfeksi pada varietas Bima Brebes yaitu penyakit Bercak Ungu yang di sebabkan oleh cendawan (Alltenaria porri), dan penyakit mosaik kuning yang di sebabkan oleh virus (Onion Yellow Dwarf Virus) yang menginfeksi varietas Bima Brebes dan Trisula, sedangkan penyakit Moler yang disebabkan oleh cendawan Fusarium oxysporum f.sp.cepae, hanya menginfeksi varietas Trisula.

\section{DAFTAR PUSTAKA}

Balai Perlindungan Tanaman Pangan dan Hortikultura. 2018. "Budidaya Bawang Merah Secara Pengendalian Hama Terpadu". Dinas Tanaman 
Pangan Hortikultura dan Perkebunan Provinsi Sumatera Barat. Padang.

Duriat, A.S. 1985. Virus-virus pada Kentang di Pulau Jawa, Identifikasi, Penyebaran, dan Kemungkinan Pengendalian. Disertasi. Universitas Padjadjaran. Bandung

Irawan, D. 2010. Bawang Merah dan Pestisida. Badan Ketahanan Pangan Sumatera Utara. Medan.

Nasiroh, U., \& Trimulyono, G. 2015. Aktivitas Antifungi Serratia marcescens terhadap Alternaria porri Penyebab Penyakit Bercak Ungu Secara in vitro. Jurnal Biologi. 4(1):13-18.

Sakti, DM., Tejasukmana, KR., Rosliani, R. 2017. Kesamaan Genetis Tanaman Bawang Merah Yang Diperbanyak Secara Biji dan Umbi. Prosiding Seminar Nasional PERIPI : 587-591.

Shahraeen N., D.E. Lesemann, and T. Gholbi. 2008. Survey for Viruses Infecting Onion, Garlic, and Leek Crops in Iran. Eppo Bull. 38:131135.
Udiarto, B. K., Setiawati, W., \& Suryaningsih, E. 2005. Pengenalan hama dan penyakit pada tanaman bawang merah dan pengendaliannya. Balai Penelitian Tanaman Sayuran. Lembang-Bandung.

Walkey, D.G.A. 1990. Virus Diseases. In Rabinowitch, H.D. and J.L. Brewster (Eds.) Onion and Allied Cropss. Volume 11 CRC Press, Boca Raton. Florida: p. 191-212.

Waluyo, N., \& Sinaga, R. 2015. Bawang merah yang dirilis oleh balai penelitian tanaman sayuran. IPTEK Tanaman Sayuran. 1(004):15.

Wiyatiningsih, S., Wibowo, A., \& Triwahyu, E. 2009. Keparahan penyakit moler pada enam kultivar bawang merah karena infeksi Fusarium oxysporum f. sp. cepae di tiga daerah sentra produksi. In Seminar Nasional Akselerasi Pengembangan Teknologi Pertanian dalam Mendukung Revitalisasi Pertanian. Fakultas Pertanian dan LPPM UPN "Veteran" Jawa Timur. Surabaya 